\title{
From Scrolls to Scrolling
}




\section{Judaism, Christianity, and Islam - Tension, Transmission, Transformation}

Edited by Patrice Brodeur, Alexandra Cuffel, Assaad Elias Kattan, and Georges Tamer

\section{Volume 12}




\section{From Scrolls to Scrolling}

Sacred Texts, Materiality, and Dynamic Media Cultures

Edited by Bradford A. Anderson

\section{DE GRUYTER}


Die freie Verfügbarkeit der E-Book-Ausgabe dieser Publikation wurde ermöglicht durch den Fachinformationsdienst Jüdische Studien an der Universitätsbibliothek J. C. Senckenberg Frankfurt am Main und 18 wissenschaftliche Bibliotheken, die die Open-Access-Transformation in den Jüdischen Studien unterstützen.

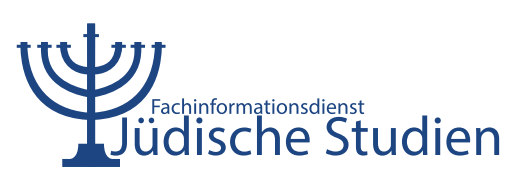

ISBN 978-3-11-062959-0

e-ISBN (PDF) 978-3-11-063444-0

e-ISBN (EPUB) 978-3-11-063146-3

ISSN 2196-405X

DOI https://doi.org/10.1515/9783110634440

\section{(cc) BY-NC-ND}

This work is licensed under a Creative Commons Attribution-NonCommercial-NoDerivatives 4.0 International License. For details go to http://creativecommons.org/licenses/by-nc-nd/4.0

\section{Library of Congress Control Number: 2020933703}

\section{Bibliographic information published by the Deutsche Nationalbibliothek}

The Deutsche Nationalbibliothek lists this publication in the Deutsche Nationalbibliografie; detailed bibliographic data are available on the Internet at http://dnb.dnb.de.

(c) 2020 Bradford A. Anderson, published by Walter de Gruyter GmbH, Berlin/Boston. The book is published with open access at www.degruyter.com.

Typesetting: Integra Software Services Pvt. Ltd.

Printing and binding: $\mathrm{CPI}$ books $\mathrm{GmbH}$, Leck

www.degruyter.com 
